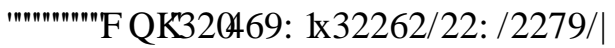

\title{
FLAME SPREAD IN CABLE TRAY FIRES AND ITS MODELING IN FIRE SIMULATION CODES
}

\section{FLAMMENAUSBREITUNG BEI BRÄNDEN VON KABELBÜNDELN UND DEREN MODELLIERUNG IN BRANDSIMULATIONSMODELLEN}

\author{
Röwekamp M. ${ }^{1}$, Klein-Heßling W. ${ }^{1}$, Riese O. ${ }^{2}$, Berg Heinz-Peter ${ }^{3}$
}

(1) Gesellschaft für Anlagen- und Reaktorsicherheit (GRS) mbH, Schwertnergasse 1, 50667 Köln, Germany

(2) Institut für Baustoffe, Massivbau und Brandschutz (iBMB), Beethovenstraße 52, 38106 Braunschweig, Germany

(3) Bundesamt für Strahlenschutz

Willy Brandt-Str. 5, 38226 Salzgitter, Germany

e-mails: (1) marina.roewekamp@grs.de (2) o.riese@ibmb.tu-bs.de (3) hberg@bfs.de

\begin{abstract}
A vertical cable routing on different trays has been observed as worst case in case of fire. PVC (polyininl chloride) or FRNC (fire retardant non-corrosive) polymers have been used as cable insulation materials for cables typically being installed in German NPP. Each experiment has been repeated under pre-heated conditions. A propane gas burner has been used for igniting cables and an ethanol pool for pre-heating. Two different types of fire simulation codes (one 'lumped parameter' code - COCOSYS - and two threedimensional computational fluid dynamics (CFD) codes - FDS and CFX) have been investigated with respect to their potential for predicting the experimental results. There were significant differences in the way of performing flame spread calculations in the codes. However, none of the models applied in the frame of this benchmark exercise was able to predict the cable flame spread in an adequate manner.
\end{abstract}

Keywords: cable fires, fire simulation, benchmark exercise

Zusammenfassung. Die vertikale Kabeltrassierung hat sich als die ungünstigste Konstellation bei einem Brandfall erwiesen. In deutschen Kernkraftwerken werden überwiegend PVC (Polyvinylchlorid) bzw. - sogenannte FRNC (Brand verzögernde noch korrosive) Polymere als Isolierungsmaterial für Kabel verwendet. Jedes Experiment wurde zweimal durchgeführt, einmal mit Vorheizung der verwendeten Kabel und einmal ohne. Zwei verschiedene Arten von Brandsimulationsprogrammen (ein thermohydraulischer Code - COCOSYS - und zwei dreidimensionale Codes, die fluiddynamische Feldmodelle nutzen - FDS und CFX) wurden hinsichtlich über Möglichkeiten untersucht, die experimentellen Ergebnisse vorherzusagen. Dabei wurden signifikante Unterschiede in der Vorgehensweise bei der Durchführung der Berechnungen der Ausbreitung der Flammen in den Rechenprogrammen festgestellt. Es ist festzuhalten, dass keines der in den Vergleichsrechnungen eingesetzten Modelle in der Lage waren, die Ausbreitung der Flamme bei Kabelbränden adäquat vorherzusagen.

Schlagwörter: Kabelbrand, Brandsimulation, Vergleichsrechnungen 


\section{FLAME SPREAD IN CABLE TRAY FIRES AND ITS MODELING IN FIRE SIMULATION CODES}

\section{Introduction}

A series of four full scale cable tray fire experiments has been carried out at iBMB of Braunschweig University of Technology in the frame of a benchmark exercise (BE). Two types of fire simulation codes have been applied by members of the International Collaborative Project to Evaluate Fire Models for Nuclear Power Plant Applications within this benchmark exercise: one lumped parameter code COCOSYS and two three-dimensional computational fluid dynamics codes (FDS and CFX).

\section{Specification}

The cable fire experiments have been carried out in a special fire compartment (iBMB test facility) with an inner floor area of $3.6 \mathrm{~m} \times 3.6 \mathrm{~m}$ (see Figure 1). The inner room height is $5.6 \mathrm{~m}$. The (naturally ventilated) gas exchange takes place through an opening of $0.7 \mathrm{~m}$ width and $3.6 \mathrm{~m}$ height, which is reduced by a wall of $1.4 \mathrm{~m}$ height to an area of approx. $1.5 \mathrm{~m}^{2}$. Smoke gases released are collected in a hood with an exhaust duct located over the opening and led to a smoke gas cleaning system. The gases are analyzed and the heat release rate (HRR) is derived.

As primary pilot fire a liquid pool of $0.5 \mathrm{~m}^{2}$ floor area, filled with (ethylene alcohol), has been assumed. As worst case scenario, a maximum pre-heating (PH) temperature in the surrounding of the cables of $200{ }^{\circ} \mathrm{C}$ has been reached. For measuring the burning rate of the liquid pool, the fuel pan is mounted on a weight scale. The cables on the tray are ignited by means of a propane gas burner. In case of FRNC (fire retardant non-corrosive) insulated cables $150 \mathrm{KW}$ output power has been used, in case of PVC (polyvinylchloride) cables $50 \mathrm{~kW}$. With $\mathrm{PH}$, the ignition burner was activated after $1200 \mathrm{~s}$. The pre-fabricated trays filled with cables were mounted on a weight scale on top of the ceiling. A vertical thermocouple (TR 5 1-7) tree was located $40 \mathrm{~cm}$ in front of the cable tray for measuring the gas temperature in seven heights close to the surface of the cable bundles. An overview of the test results is given in [1] including all measured parameters. High voltage power cables as well as low voltage 
instrumentation and control (I\&C) cables with PVC as well as FRNC insulation material have been tested, installed on a tray within two separated cable bundles $(10 \mathrm{~cm}$ each). The vertical ladder type cable trays are filled with cables with the corresponding measuring equipment as depicted in Figure 2. The cables are mounted on the trays with German standard cable clamps. The lowest series of thermocouples are installed approx. $70 \mathrm{~cm}$ above the lower side of the tray. The distance between the different measuring levels is $40 \mathrm{~cm}$, the one between the highest series of measuring devices and the upper edge of the tray $10 \mathrm{~cm}$. The measuring devices of each row have numbers starting at the lowest level up to the highest one.

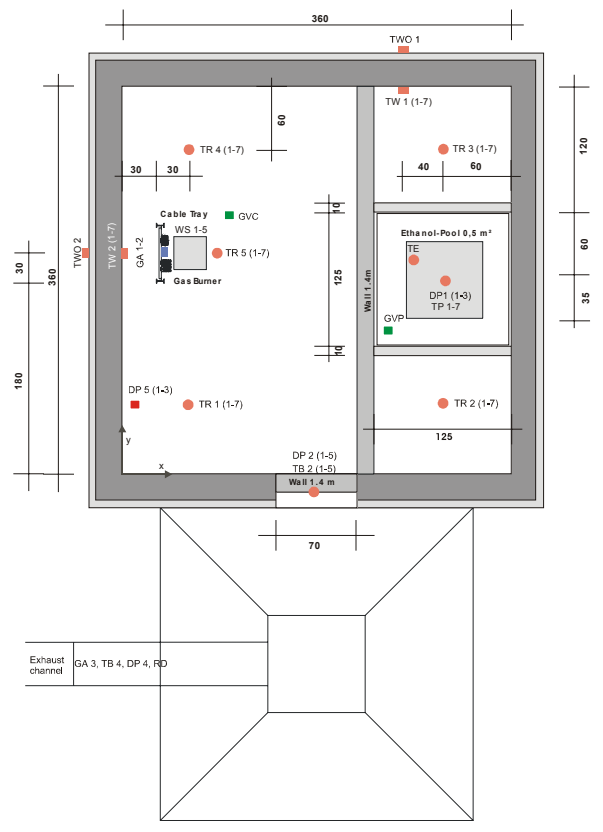

Fig. 1. Top view of the fire compartment for the cable fire tests

\section{Experimental results}

A brief overview over the results from the BE No. 5 test series is given in Figures 3 and 4. The HRR from test 1 (FRNC, without $\mathrm{PH}$ ) and test 2 (FRNC, with $\mathrm{PH}$ ) and the corresponding ignition burner power output are given in Figure 3 and for test 3 (PVC, without $\mathrm{PH}$ ) and test 4 (with $\mathrm{PH}$ ) in Figure 4, accordingly. The HRR resulting from the combustible material is low in case of FRNC insulation material (see Figure 3). In case of PH, slightly higher values are observed, with a maximum of up to $100 \mathrm{~kW}$. An 
increase of the burner output of up to $300 \mathrm{~kW}$ after 30 min duration (test 2) and $40 \mathrm{~min}$ (test 1), respectively, have no significant effects on the HRR.

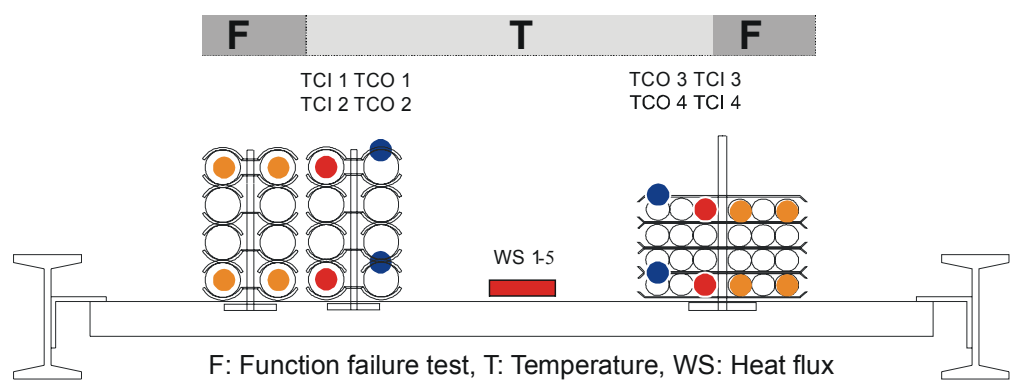

Fig. 2. Vertical cable tray; two cable bundles; left: power cables, right: I\&C cables, TCO: Temperatures on cables, TCI: Temperatures in cables, WS 1-5: Heat flux to cable bundle surface

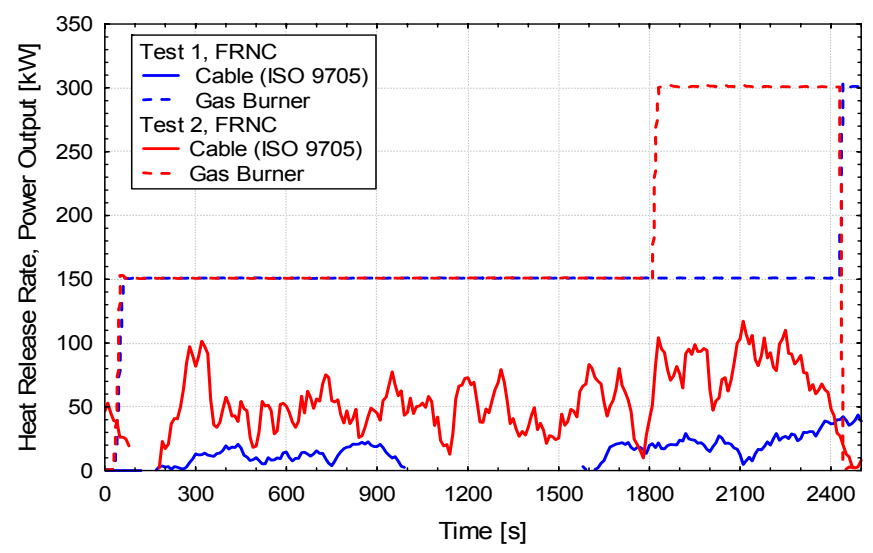

Fig. 3. Heat release rate and gas burner output: test 1 and test 2, FRNC

In case of PVC insulation material (see Figure 4, test 3), the cables (power cables as well as I\&C ones) ignited after a short time and a HRR with a peak at $330 \mathrm{~kW}$ after approx. $12 \mathrm{~min}$. In case of test 4 (see Figure 4) with pre-heated cables, the I\&C cables ignited notably later and the power cables could not be ignited with a $50 \mathrm{~kW}$ burner power output. As a reaction of increasing the burner capacity to up to $100 \mathrm{~kW}$ after approx. $15 \mathrm{~min}$, the power cables ignited and a second peak HRR at $200 \mathrm{~kW}$ was found.

During the pre-heating phase of approx. $20 \mathrm{~min}$, the environmental temperature in the near vicinity of the cable insulation is determined to reach a maximum of $200{ }^{\circ} \mathrm{C}$. The major issue of the tests was the flame spread on the cables. The tests show that the FRNC cables have 
significantly better characteristics in case of a fire. No substantial flame spread takes place, even in case of pre-heating. PVC cables could be ignited with a burner output of $50 \mathrm{~kW}$. In contrary, the FRNC cables could be ignited at a burner output of $150 \mathrm{~kW}$. The pre-heating has complex effects on the fire behaviour of the cables. Gases, which are not ignited during the phase of pre-heating, may also be pyrolyzed and transported to the cable surroundings and may leave the fire compartment.

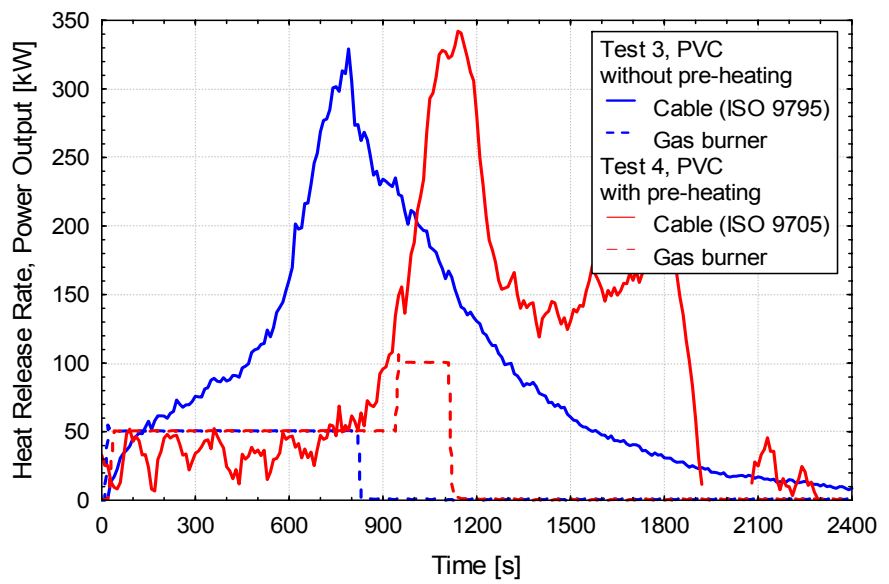

Fig. 4. Heat release rate and gas burner output: test 3 and test 4, PVC

\section{Calculations by fire simulation codes}

Table 1 provides details about the different fire models used in the benchmark exercise to model the flame spread in a cable tray fire with regard to the treatment of pyrolysis. Blind and open calculations have been performed [2]. Figure 5 shows the measured and the calculated surface temperature of I\&C cables at the cable tray in $1.5 \mathrm{~m}$ height $(2 \mathrm{~m}$ over the compartment floor) for test 1 .

In COCOSYS, an empirical approach has been chosen to calculate the heat release rate and the flame spread of a given cable tray fire scenario. The model uses a specified pyrolysis rate for the cables being represented by a rectangular slab as well. The propagation velocity depends on the assigned surrounding temperature of the target. A database for this property has been derived from earlier experimental results, gained in the same compartment under similar conditions considering different pre-heating temperatures. For 
the open calculations, COCOSYS was extended by introducing a remaining mass fraction for incomplete burn down of cables.

Table 1. Details about the different fire models

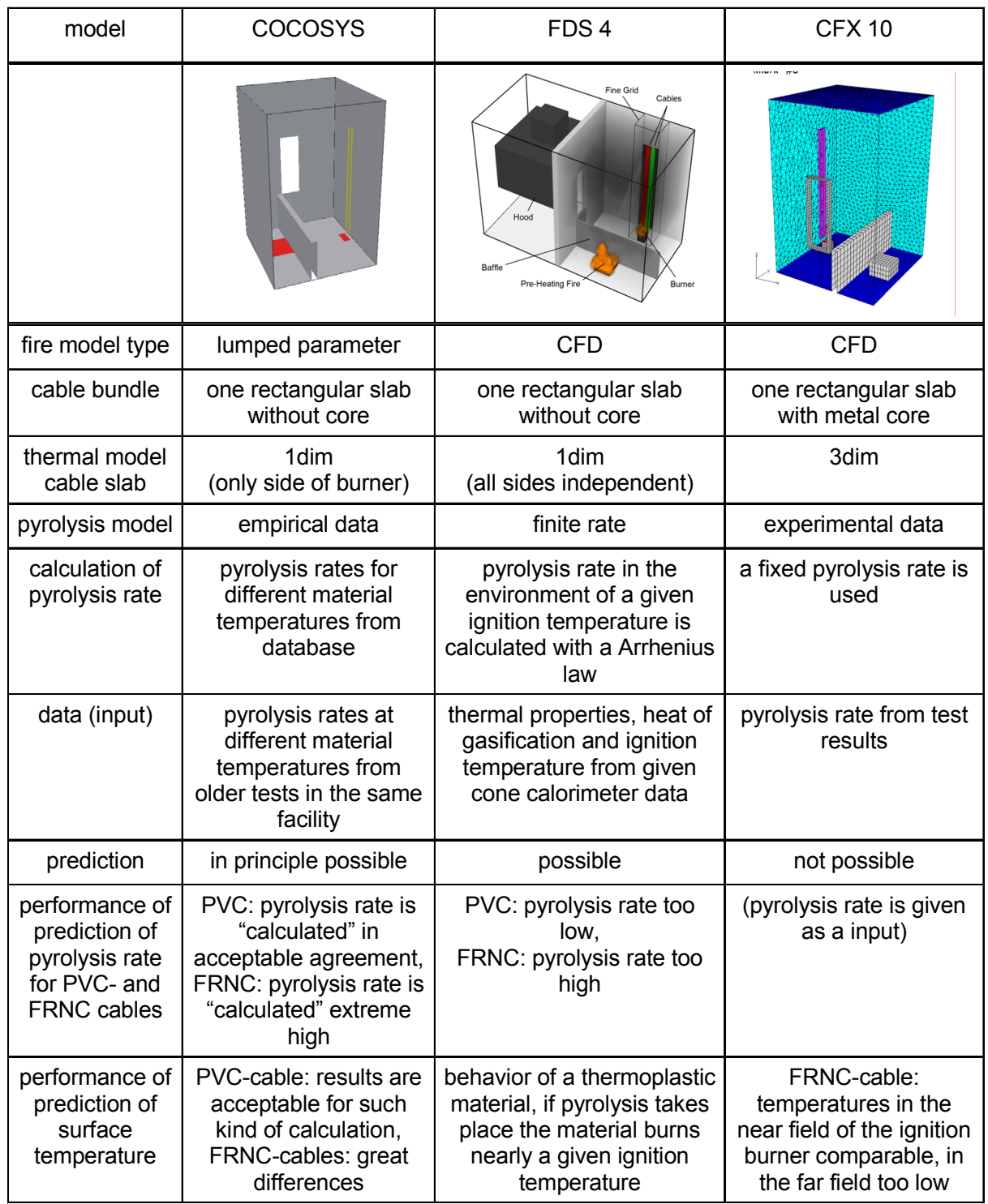




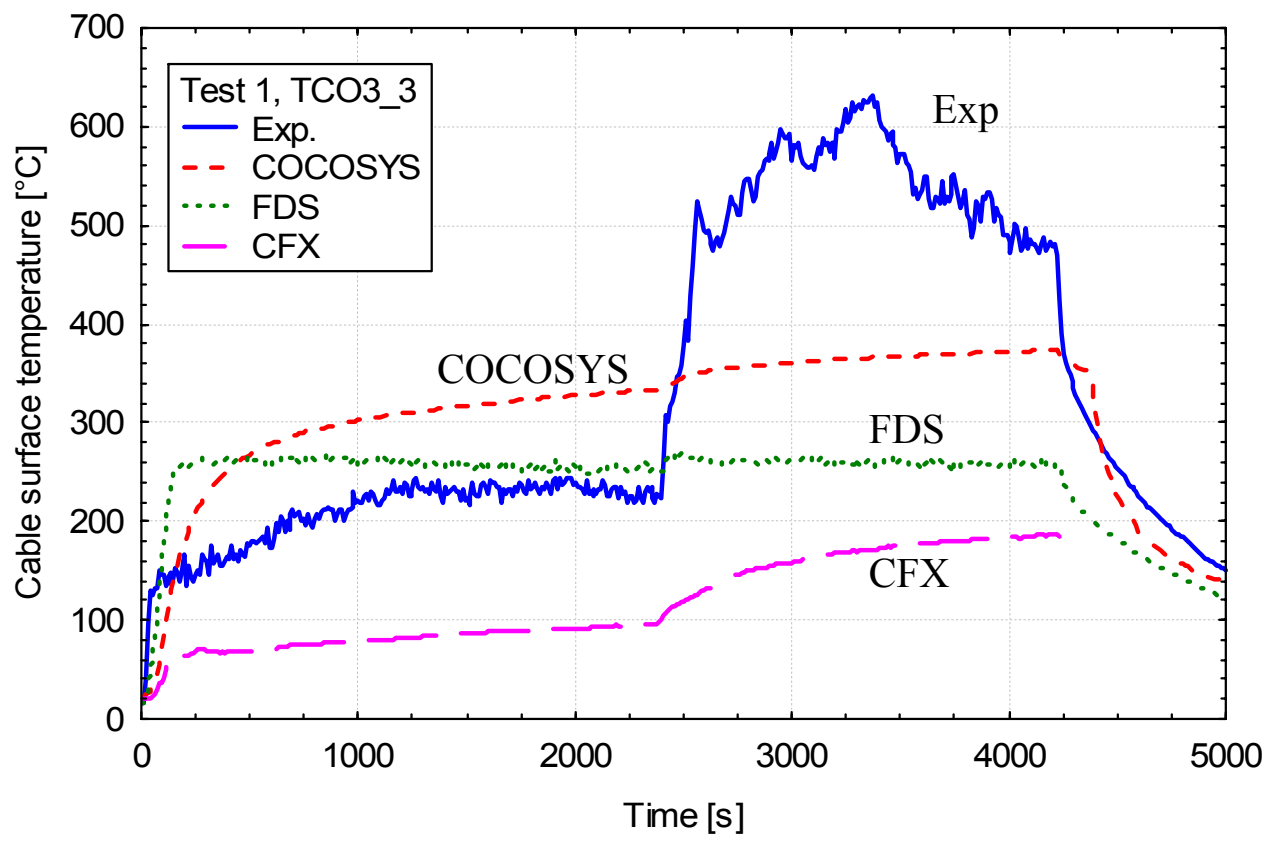

Fig. 5. FRNC I\&C cable surface temperatures (TCO3_3), Test 1 - measurement (Exp.) and code calculation results in $1.5 \mathrm{~m}$ height at tray

In CFX, while no pyrolysis model is included, the basic elements for checking the ignition temperature at each boundary cell of a solid do exist, and this can be coupled to a specified pyrolysis rate. The work to build up such a model has been started but is not yet finished. Thus, the exercise to model a burning cable has been simplified in a way that a constant pyrolysis rate (from the experimental data) is initiated once the ignition temperature at any one of the CFD cells at the cable bundle is reached. The calculated gas temperatures are in a better agreement to the experimental data in the direct environment of the cables for the first phase with $150 \mathrm{~kW}$ power output, but too low for the second phase with $300 \mathrm{~kW}$ power output.

The thermoplastic model in FDS is the only predictive pyrolysis model which has been used in this benchmark exercise. Modeling complex objects such as cables is not one of the most suitable applications.. As a first step, it would be useful to add some general features to FDS. One possibility is to model a complex object as a collection of small 'particles', each of them having properties similar to the solid material. Cable bundles could be treated as a collection of small cylinders, for which the interaction with each other would be almost completely separate from the gas phase grid [1]. 


\section{Conclusions}

It should be pointed out that most of the codes are able to predict the major quantities (e.g. gas temperature, heat flux, gas velocities, etc.) for a given fire scenario reasonably, if the heat release rate from the fire is given as input. But to predict the HRR and the flame spread for a given application as this benchmark exercise is a completely different and highly complex task.

At present, none of the codes applied in the benchmark exercise for calculating ignition, pyrolysis and flame spread of typical vertically routed cables can be used as a reliable predictive tools [2].

There are different sources of uncertainties arising in the code predictions of the experimental results. One source of model uncertainties are the thermophysical data gained from small size cone calorimeter experiments being used as input data for the fire simulation codes. Another uncertainty results from the fact that the pyrolysis and heat transfer models used by the fire models only incompletely describe the decomposition and heat build-up of complex materials and structures such as cables. Improvements and further model developments are necessary to reduce these uncertainties.

The need for further experimental activities has resulted in an international project by OECD/NEA called PRISME (Fire Propagation in Elementary Multi-room Scenarios), which is scheduled from 2006 to 2010. Within PRISME, additional scenarios tailored for code validation purposes are investigated, in particular regarding fire and smoke spreading, covering also multi-room fires.

\section{References}

1. Riese, O., D. Hosser, M. Roewekamp, Evaluation of Fire Models for Nuclear Power Plant Applications: Flame Spread in Cable Tray Fires, International Panel Report - Benchmark Exercise No. 5, GRS Report Number 214, Köln, November 2006

2. Roewekamp, M. et al, International Collaborative Fire Modeling Project (ICFMP) - Summary of Benchmark Exercises 1 to 5, GRS Report Number 227, Köln, in preparation 


\section{FLAMMENAUSBREITUNG BEI BRÄNDEN VON KABELBÜNDELN UND DEREN MODELLIERUNG IN BRANDSIMULATIONSMODELLEN}

\section{Einleitung}

Eine Serie von Experimenten mit vier Kabelbündeln in Originalgröße wurden am iBMB der Technischen Universität Braunschweig durchgeführt. Zwei Arten von Brandsimulationsprogrammen wurden von den Teilnehmern eines internationalen Projekts zur Bewertung von Brandmodellen für kerntechnische Anwendungen für Vergleichsrechnungen eingesetzt: der sogenannte „lumped parameter“ Code COCOSYS sowie zwei dreidimensionale fluiddynamische Modelle (FDS und CFX).

\section{Spezifizierung des Experiments}

Die Kabelbrandexperimente wurden in einer speziellen Einrichtung mit einer Bodenfläche von 3,6 m x 3,6 m (Abb. 1) durchgeführt. Die Raumhöhe beträgt 5,6 m. Der (natürlich ventilierte) Gasaustausch findet durch eine Öffnung von 0,7 m Breite und 3,6 m Höhe statt, die durch eine Mauer von $1,4 \mathrm{~m}$ Höhe auf eine Fläche von ca. $1,5 \mathrm{~m}^{2}$ reduziert werden kann. Freigesetzte Rauchgase werden in einer Haube gesammelt und zu einem Rauchgasreinigungssystem geführt. Die Gase werden analysiert und daraus die Energiefreisetzungsrate abgeleitet.

Als Initialbrand wurde ein flüssiger Pol von $0,5 \mathrm{~m}^{2}$ Fläche unterstellt, gefüllt mit Äthylenalkohol. Im ungünstigsten Fall wurde eine maximale Vorheiztemperatur in der Umgebung der Kabel von $200{ }^{\circ} \mathrm{C}$ erreicht. Um die Abbrandrate des flüssigen Pools zu messen, wurde das Brennstoffbecken auf einer Gewichtsskala montiert. Die Kabel auf den Trassen wurden mit Hilfe eines Propangasbrenners entzündet. Im Fall der Kabel mit Brand verzögernder, nicht korrosiver (FRNC) Isolierung wurde eine Ausgangsleistung von $150 \mathrm{~kW}$ verwendet, im Fall der PVC-Kabel $50 \mathrm{~kW}$. Mit Vorheizung wurde der Entzündungsbrenner nach 1200 Sekunden aktiviert. Die vorgefertigten Kabeltrassen wurden auf einer Gewichtsskala direkt an der Decke montiert. Ein vertikaler Thermoelementestrang wurde $40 \mathrm{~cm}$ vor der Kabeltrasse installiert, um die Gastemperatur in sieben 
verschiedenen Höhen nahe der Oberfläche der Kabelbündel zu messen. Ein Überblick über die Testergebnisse einschließlich aller gemessenen Parameter wird in [1] beschrieben. Hochspannungsleistungskabel sowie Niederspannungskabel für Instrumentierung sowohl mit PVC als auch mit FRNC Isolationsmaterial wurden getestet, auf einer Kabeltrasse innerhalb zweier separater Kabelbündel von jeweils $10 \mathrm{~cm}$ Breite. Die vertikalen leiterartigen Kabeltrassen sind mit Kabeln und den entsprechenden Messinstrumenten versehen (siehe Abb. 2). Die Kabel sind auf den Trassen mit deutschen Standardkabelklammern befestigt. Die unterste Reihe von Thermoelementen sind ca. $70 \mathrm{~cm}$ oberhalb der Unterseite der Trasse installiert. Der Abstand zwischen den verschiedenen Messebenen beträgt 40 $\mathrm{cm}$, der Abstand zwischen der höchsten Reihe der Messelemente und der oberen Ecke der Trasse $10 \mathrm{~cm}$.

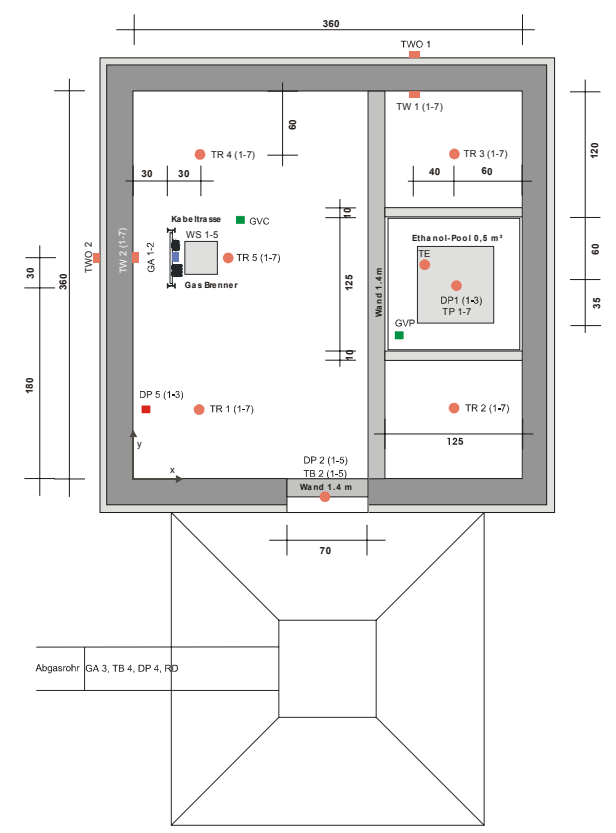

Abb. 1. Blick von oben auf die Brandeinrichtung für die Kabelbrandtests

\section{Experimentelle Ergebnisse}

Ein kurzer Überblick über die experimentellen Ergebnisse ist in den Abb. 3 und 4 gegeben. Die Energiefreisetzungsrate aus Test 1 (FRNC, ohne Vorheizung) und Test 2 (FRNC, mit Vorheizung) sowie die entsprechenden 
Gasbrennerleistungen sind in Abb. 3 dargestellt, in Abb. 4 die Ergebnisse für PVC- anstelle der FRNC-Kabel. Die Energiefreisetzungsrate aus dem brennbaren Material ist klein im Fall des FRNC-Isolierungsmaterials (Abb. 3). Bei Vorheizung wurden unwesentlich höhere Werte beobachtet, mit einem Maximum von bis zu $100 \mathrm{KW}$. Eine höhere Brennleistung von bis zu $300 \mathrm{~kW}$ nach 30 Minuten Dauer (Test 2) und 40 Minuten (Test 1) führten zu keinen nennenswerten Auswirkungen auf die Energiefreisetzungsrate.

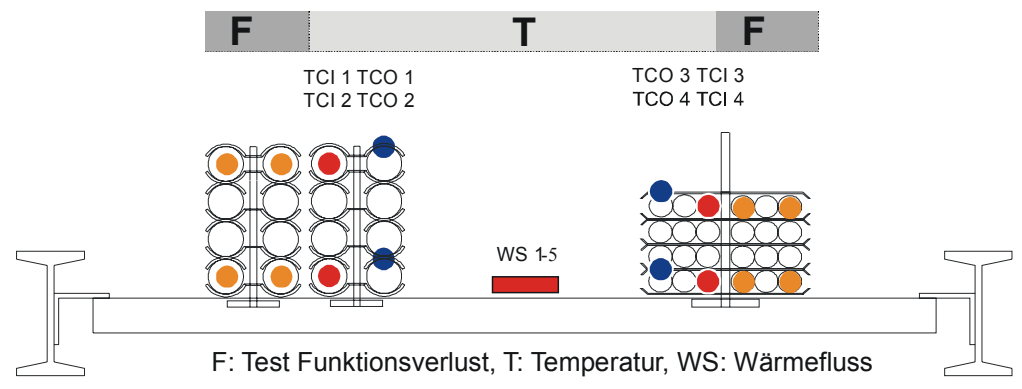

Abb. 2. Vertikale Kabeltrasse; zwei Kabelbündel, links: Leistungskabel, rechts: Niderspannungskabel, TCO: Temperatur auf den Kabeln, TCI: Temperatur in den Kabeln

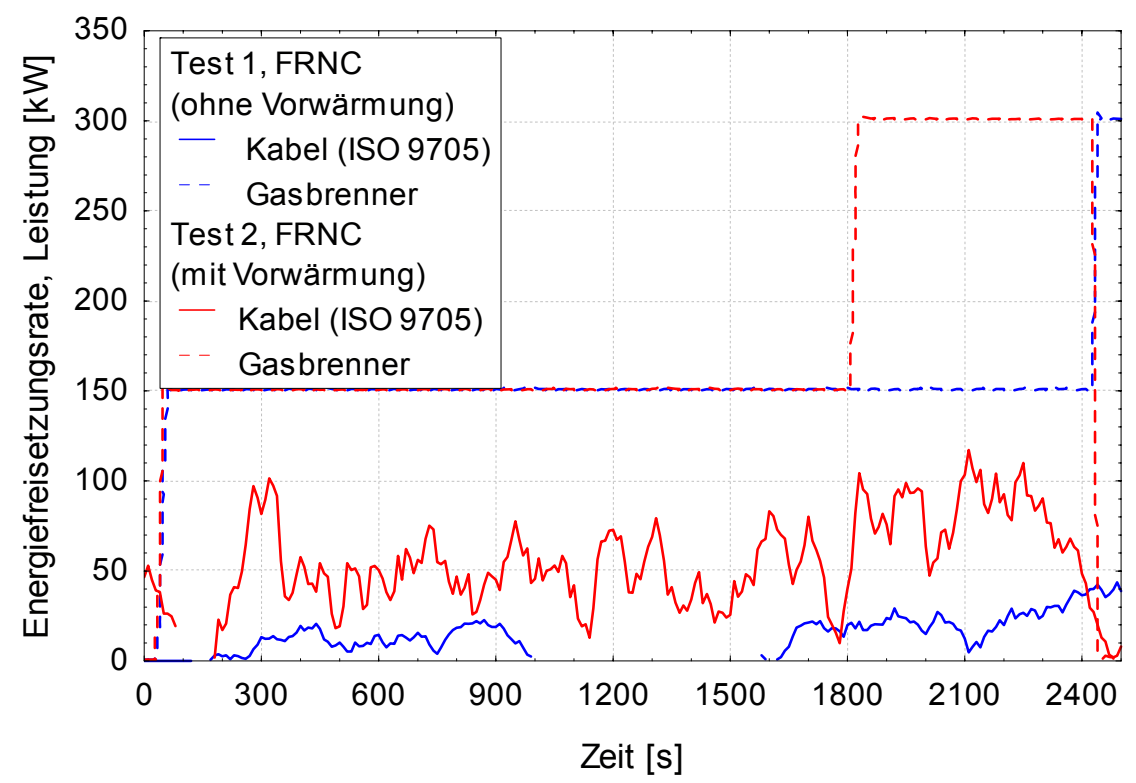

Abb. 3. Energiefreisetzungsrate und Gasbrennerleistung: Test 1 und Test 2, FRNCIsolierung

Bei der Verwendung von PVC als Isolierungsmaterial (siehe Abb. 4, Test 3) entzündeten sich beide Kabeltypen nach kurzer Zeit, eine 
Energiefreisetzungsrate mit einem Höchstwert bei $330 \mathrm{~kW}$ wurde nach 12 Minuten gemessen. Im Test 4 (siehe Abb. 4) mit vorgeheizten Kabeln entzündeten sich die Niederspannungskabel deutlich später und die Leistungskabel konnten mit einem Gasbrenner mit $50 \mathrm{~kW}$ Leistung überhaupt nicht entzündet werden. Bei einer Erhöhung der Brennerleistung auf $100 \mathrm{~kW}$ entzündeten sich nach ca. 15 Minuten die Leistungskabel und ein zweiter Peak der Energiefreisetzungsrate wurde bei $200 \mathrm{~kW}$ gefunden. Aufgrund der Vorheizungsphase von ca. 20 Minuten beträgt die Umgebungstemperatur in der Nähe der Kabel bis zum $200{ }^{\circ} \mathrm{C}$. Die Hauptaufgabe dieser Tests war die Ermittlung der Flammenausbreitung auf den Kabeln. Die Experimente zeigen bei den FRNC-Kabeln ein deutlich besseres Verhalten bei einem Brand. Es fand keine substantielle Flammenausbreitung statt, auch nicht im Fall einer Vorheizung. PVC-Kabel konnten mit einem Gasbrenner mit einer Leistung von $50 \mathrm{~kW}$ entzündet werden, für FRNC-Kabel waren $150 \mathrm{~kW}$ erforderlich. Die Vorheizung zeigte komplexe Effekte des Brandverhaltens auf den Kabeln. Gase, die nicht während der Vorheizungsphase entzündet werden, können auch pyrolysiert und in der Umgebung der Kabel transportiert werden oder den Brandabschnitt verlassen.

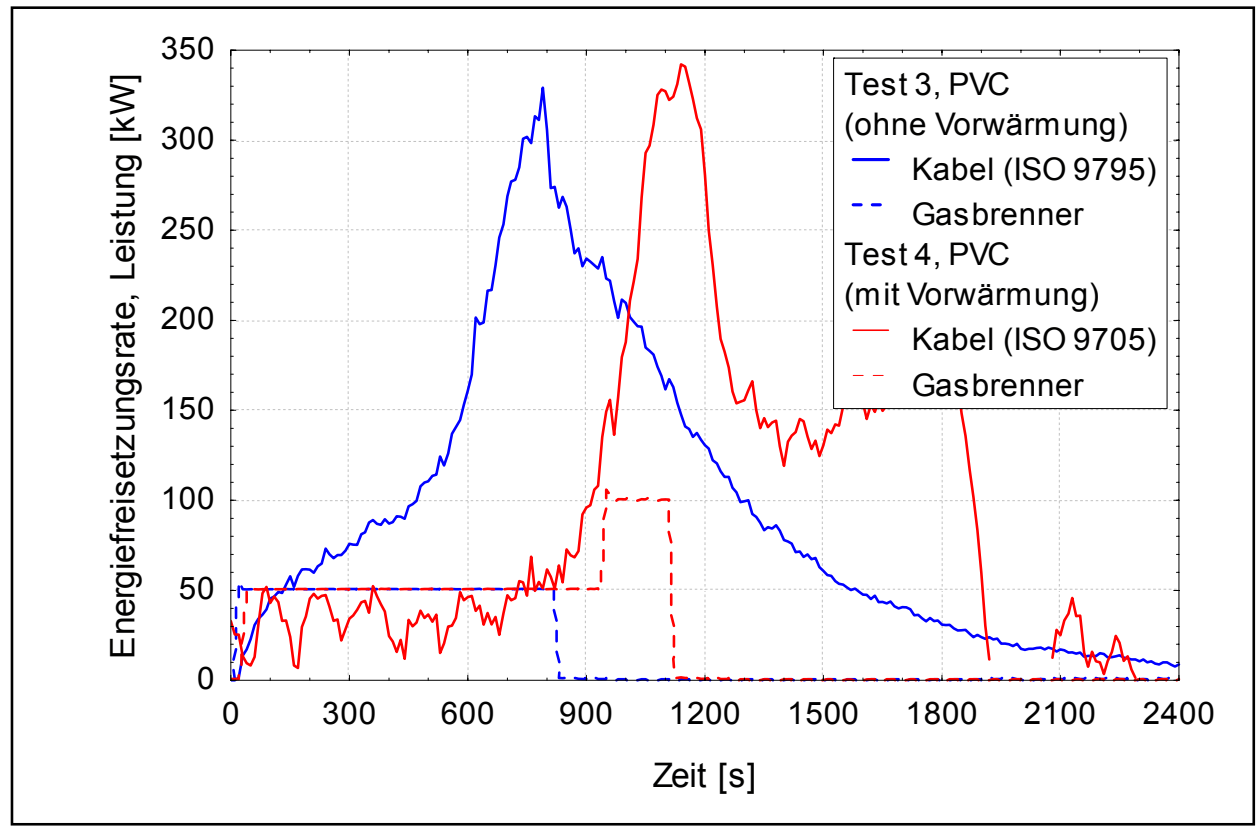

Abb. 4. Energiefreisetzungrate und Gasbrennerleistung: Test3 und Test 4, PVC

\section{Berechnungen mit den Brandsimulationsprogrammen}


Tabelle 1 fasst Details über die verschiedenen Brandmodelle zusammen, die in diesem Vergleich verwendet wurden, um die Flammenausbreitung bei einem Kabeltrassenbrand hinsichtlich der Behandlung der Pyrolyse zu modellieren. Blinde und offene Rechnungen wurden durchgeführt [2]. Abb. 5 zeigt die gemessenen und die berechneten Oberflächentemperaturen der Niederspannungskabel an der Kabeltrasse in einer Höhe von $1,5 \mathrm{~m}(2 \mathrm{~m}$ über dem Boden der Testeinrichtung) für den Test 1.

Tabelle 1. Details über die unterschiedlichen Brandmodelle

\begin{tabular}{|c|c|c|c|}
\hline Modell & COCOSYS & FDS 4 & CFX 10 \\
\hline Brandmodelltyp & "lumped parameter" & CFD & CFD \\
\hline Kabelbündel & $\begin{array}{l}\text { Rechteckige Platte } \\
\text { ohne Kern }\end{array}$ & $\begin{array}{l}\text { Rechteckige Platte ohne } \\
\text { Kern }\end{array}$ & $\begin{array}{l}\text { Rechteckige Platte mit } \\
\text { Metallkern }\end{array}$ \\
\hline $\begin{array}{l}\text { Thermisches } \\
\text { Modell }\end{array}$ & $\begin{array}{c}1 \mathrm{dim} \\
\text { (eine Seite des } \\
\text { Brenners) }\end{array}$ & $\begin{array}{l}1 \mathrm{dim} \\
\text { (alle Seiten unabhängig) }\end{array}$ & 3dim \\
\hline Pyrolysemodell & Empirische Daten & endliche Raten & Experimentelle Daten \\
\hline $\begin{array}{l}\text { Berechnungen } \\
\quad \text { der } \\
\text { Pyrolyseraten }\end{array}$ & $\begin{array}{l}\text { Pyrolyseraten für } \\
\text { verschiedene } \\
\text { Materialien, } \\
\text { Temperaturen aus } \\
\text { Datenbank }\end{array}$ & $\begin{array}{l}\text { Pyrolyserate in der } \\
\text { Umgebung einer } \\
\text { gegebenen } \\
\text { Zündtemperatur berechnet } \\
\text { mit Arrhenius-Gesetz }\end{array}$ & $\begin{array}{c}\text { Eine feste Pyrolyserate } \\
\text { wird verwendet }\end{array}$ \\
\hline Eingangsdaten & $\begin{array}{l}\text { Pyrolyseraten bei } \\
\text { verschiedenen } \\
\text { Materialtemperaturen } \\
\text { aus alten Tests }\end{array}$ & $\begin{array}{l}\text { Thermische Eigenschaften } \\
\text { und Zündtemperatur aus } \\
\text { gegebenen } \\
\text { Kalorimeterdaten }\end{array}$ & $\begin{array}{l}\text { Pyrolyseraten aus } \\
\text { Testergebnissen }\end{array}$ \\
\hline Vorhersage & Prinzipiell möglich & möglich & Nicht möglich \\
\hline $\begin{array}{c}\text { Durchführung } \\
\text { der Vorhersage } \\
\text { der } \\
\text { Pyrolyserate }\end{array}$ & $\begin{array}{l}\text { PVC: Pyrolyserate in } \\
\text { guter } \\
\text { Übereinstimmung, } \\
\text { FRNC: Pyrolyserate ist } \\
\text { sehr hoch }\end{array}$ & $\begin{array}{l}\text { PVC: Pyrolyserate ist zu } \\
\text { gering, } \\
\text { FRNC: Pyrolyserate ist zu } \\
\text { hoch }\end{array}$ & $\begin{array}{l}\text { (Pyrolyserate wird als } \\
\text { Eingangsinformation } \\
\text { vorgegeben) }\end{array}$ \\
\hline $\begin{array}{c}\text { Durchführung } \\
\text { der Vorhersage } \\
\text { der } \\
\text { Oberflächen- } \\
\text { temperatur }\end{array}$ & $\begin{array}{l}\text { PVC-Kabel: Ergebnisse } \\
\text { sind akzeptabel, } \\
\text { FRNC-Kabel: große } \\
\text { Unterschiede }\end{array}$ & $\begin{array}{l}\text { Verhalten eines } \\
\text { thermoplastischen } \\
\text { Materials verbrennt bei } \\
\text { einer gegebenen } \\
\text { Zündtemperatur }\end{array}$ & $\begin{array}{c}\text { FRNC-Kabel: } \\
\text { Temperatur in der Nähe } \\
\text { des Brenners } \\
\text { vergleichbar, sonst zu } \\
\text { gering }\end{array}$ \\
\hline
\end{tabular}


Im Programm COCOSYS wurde ein empirischer Ansatz gewählt, um die Energiefreisetzungsrate und die Flammenausbreitung eines gegebenen Kabeltrassenbrandszenariums $\mathrm{zu}$ berechnen. Das Modell verwendet eine spezifizierte Pyrolyserate für die Kabel, dargestellt durch eine rechteckige Platte. Die Fortpflanzungsgeschwindigkeit hängt von der Temperatur in der Umgebung des Targets ab. Eine Datenbasis für diese Eigenschaft wurde aus früheren experimentellen Ergebnissen abgeleitet, die in derselben Testeinrichtung unter ähnlichen Randbedingungen erzielt wurden. Für die offenen Rechnungen wurde COCOSYS durch die Einführung eines verbleibenden Massenanteils für nicht vollständig verbrannte Kabelreste erweitert.

Weil im CFX-Programm kein Pyrolysemodell enthalten ist, werden die Basiselemente für die Prüfung der Entzündungstemperatur an jeder Zellgrenze verwendet und mit einer spezifischen Pyrolyserate gekoppelt. Die Arbeiten sind noch nicht abgeschlossen, daher wurde zur Vereinfachung eine konstante Pyrolyserate aus dem Experiment immer dann angesetzt, wenn die Entzündungstemperatur an einer der Zellen des Kabelbündels erreicht wurde. Die berechneten Gastemperaturen sind in besserer Übereinstimmung mit den experimentellen Daten in der direkten Umgebung der Kabel für die erste Phase mit $150 \mathrm{~kW}$ Leistung, aber zu niedrig für die zweite Phase mit $300 \mathrm{~kW}$ Leistung.

Das thermoplastische Modell in FDS ist das einzige vorhersagekräftige Pyrolysemodell in diesem Vergleichstest. Für die Modellierung komplexer Systeme wie Kabel ist es aber nicht so sehr geeignet. Das System könnte durch eine Ansammlung kleiner „Teilchen“ modelliert werden, von denen jedes Eigenschaften des Materials hat. Kabelbündel könnten als eine Ansammlung schmaler Zylinder dargestellt werden [1].

\section{Schlussfolgerungen}

Grundsätzlich sind die meisten Rechenprogramme in der Lage, die wesentlichen Größen (z. B. Gastemperatur, Wärmestrom) für ein gegebenes Szenarium vernünftig vorherzusagen, wenn die Energieerzeugungsrate des entsprechenden Brandes als Eingangsdaten vorgegeben werden. Die Vorhersage der Energieerzeugungsrate und der Flammenausbreitung für eine Kon-stellation wie oben beschrieben ist komplett anders und eine sehr komplexe Aufgabe. Zur Zeit kann keines der Rechenprogramme in diesem 
Flammenausbreitung bei bränden von kabelbündeln.....

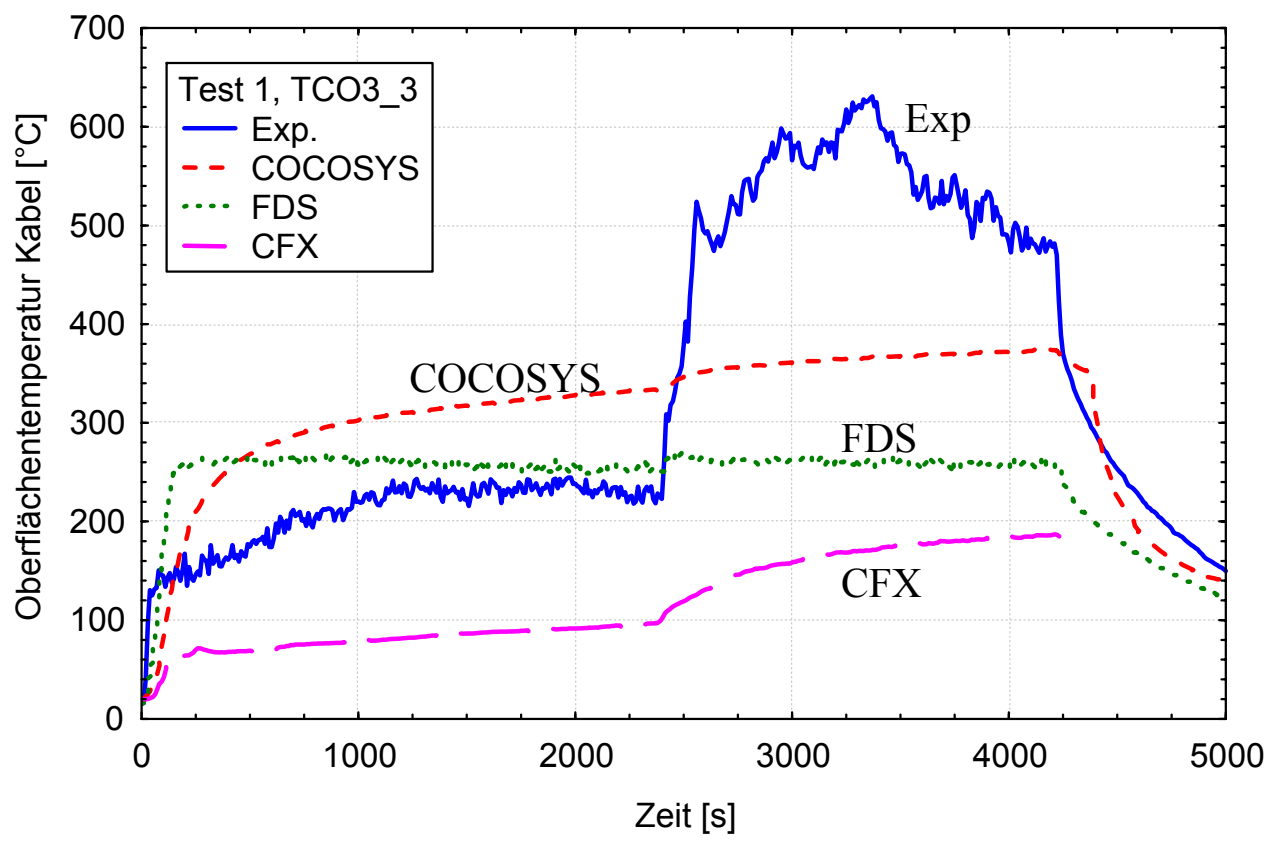

Fig. 5. Oberflächentemperaturen von FRNC Niederspannungskabeln (TC03_3), Test 1 experimentelle Messungen und Berechnungen in 1,5 m Höhe der Kabeltrasse

Vergleichs-test zur Berechnung der Entzündung, Pyrolyse und Flammenausbreitung eines vertikalen Kabelbündels zuverlässige Vorhersagen treffen [2]. Dabei sind die Ursachen der Unsicherheiten in den Vorhersagen der experimentellen Ergebnisse sehr unterschiedlich. Eine Quelle der Modellunsicherheiten sind die thermophysikalischen Daten, die aus kleinen Kalorimeterexperimenten abgeleitet und als Eingangsdaten für die Rechnungen verwendet werden. Eine andere Unsicherheit resultiert aus der Tatsache, dass die Pyrolyse und Wärmetransfermodelle die Zerlegung und Aufheizung von komplexen Materialien und Strukturen wie Kabel nur unvollständig beschreiben. Verbesserungen und Modellweiterentwicklungen sind notwendig, um diese Unsicherheiten zu verringern. Die Notwendigkeit weiterer experimenteller Aktivitäten hat zu einem internationalen Projekt der OECD/NEA, genannt PRISME, geführt, das seit 2006 läuft und bis 2010 geplant ist. Dabei werden zusätzliche Szenarien im Hinblick auf die Validierung von Brandsimulationsprogrammen untersucht, insbesondere hinsichtlich Brand- und Rauchausbreitung in mehrere Räume. 
